\title{
Modification of the microimmunofluorescence test to provide a routine serodiagnostic test for chlamydial infection
}

\author{
JOHN D. TREHARNE, S. DAROUGAR, AND BARRIE R. JONES \\ From the Virus Laboratory, WHO Collaborating Centre for Reference and Research on Trachoma \\ and other Chlamydial Infections, Department of Clinical Ophthalmology, Institute of Ophthalmology, \\ University of London, London
}

SUMMARY A modification of the microimmunofluorescence test to provide a practicable routine serodiagnostic test for detecting and characterising chlamydial infection is described which uses four antigen pools, one of which corresponds with each of the four main clinical and epidemiological types of chlamydial infection. The three subgroup A Chlamydia (Chlamydia trachomatis) pools are: pool 1, hyperendemic trachoma TRIC agent serotypes $A, B$, and C; pool 2, paratrachoma TRIC agent serotypes D, E, F, G, H, I, and K; pool 3, lymphogranuloma venereum (LGV) agent serotypes L1, L2, and L3. Pool 4 contained four representative isolates of subgroup B Chlamydia (Chlamydia psittaci).

For routine purposes sera need be screened only against these four representative antigen pools. This will detect antibody and indicate which clinical and epidemiological type of chlamydial infection is implicated, thereby clearly distinguishing those infections that are due to $C$. psittaci. The pattern of the cross-reactions may indicate the individual serotype involved, and further titration requiring a maximum of four individual antigens is sufficient to determine the serotype. The slight loss in sensitivity (twofold) is more than compensated for by the reduction in cost and the tenfold increase in the total number of sera which can be examined.

Serological diagnosis of chlamydial infections until recently has relied on the relatively insensitive complement-fixation test (CFT). This test is capable of detecting only antibody to the heat stable group antigen, which is common to both subgroup $A$ and subgroup B Chlamydia (C. trachomatis and $C$. psittaci). It is therefore of limited diagnostic value.

The microimmunofluorescence (micro-IF) test devised by Wang and Grayston (1970) has divided subgroup A Chlamydia-that is, C. trachomatis, which includes the (TRIC) agents of trachoma (TR) and inclusion conjunctivitis (IC) and of lymphogranuloma venereum (LGV)-into a number of distinct serotypes. Using this classification, the presence of type-specific antibodies has been demonstrated in sera from patients with chlamydial infection (Wang and Grayston, 1971; Dwyer et al., 1972; Hanna et al., 1972). However, the full test

Received for publication 10 November 1976 titrating against as many as 14 antigens is both time consuming and expensive. We present in this paper a modification which is much simpler.

Jones (1975) has recently made an epidemiological classification of trachoma into three classes that $\frac{0}{3}$ correlate importantly with their public health $\rightarrow$ significance, as follows: class 1 , blinding hyperendemic trachoma of eye-to-eye transmission; $\tilde{N}$ class 2 , non-blinding endemic trachoma of eye-toeye transmission; class 3 , paratrachoma-that is, $N$ TRIC agent infection of sexual transmission with $\underset{\omega}{N}$ occasional transfer from the genital tract to the eye.

The essential difference between classes 1 and 20 seems to result from the higher and long-continued $\overline{\mathbb{D}}$ pressure of ocular infection and reinfection by both $\stackrel{\odot}{+}$ Chlamydia and bacteria in blinding trachoma(class 1 ). Classes 1 and 2 have yielded TRIC serotypes A, B, $\mathrm{Ba}$, or $\mathrm{C}$, although a few ocular isolates have been serotypes $D$ and $E$ commonly spread by sexual $\stackrel{\mathbb{Q}}{\square}$ transmission (Treharne et al., 1971). From class 3 O (paratrachoma) the isolates have been of TRIC types 510 
D, E, F, G, H, I, and $\mathrm{K}$ with the exception of a few isolates of type $B$ and type $C$.

These considerations made it desirable to simplify the present cumbersome micro-IF test and to develop a simple test that could give results of the maximum clinical and epidemiological value. This would be provided by measuring separately antibody to (a) subgroup A Chlamydia serotypes generally responsible for hyperendemic trachoma (class 1 and 2 trachoma, Jones, 1975); (b) subgroup A Chlamydia serotypes generally responsible for genital or ocular infection of sexual transmission-that is, paratrachoma (class 3 trachoma, Jones, 1975); (c) subgroup A Chlamydia serotypes generally responsible for lymphogranuloma venereum; and (d) subgroup BChlamydia infections of man generally arising from birds or other animals, though it should be noted that certain isolates from LGV have been of this nature.

\section{Material and methods}

\section{CHLAMYDIAL ISOLATES}

These comprised (a) hyperendemic trachoma isolates of $C$. trachomatis A/HAR-1/OT, B/TW-5/OT, C/UW-1/OT; (b) paratrachoma isolates of $C$. trachomatis D/IC-Cal-8/ON, E/DK-20/ON, F/MRC301/GU, G/IOL-238/R, H/UW-4/GCX, I/UW-12/ GU, K/UW-31/GCx; (c) lymphogranuloma venereum isolates of $C$. trachomatis $\mathrm{L} 1 / 440 / \mathrm{LN}, \mathrm{L} 2 / 434 /$ $\mathrm{Bu}, \mathrm{L} 3 / 404 / \mathrm{LN}$; and $(d)$ selected Chlamydia subgroup B isolates of $C$. psittaci-33-L isolated from a patient with lymphogranuloma venereum (Schachter and Meyer, 1969), A-22/18 isolated from a sheep with enzootic abortion, A-10 isolated from the eye of a guinea-pig with inclusion conjunctivitis (Murray, 1964), IOL-395/0 isolated from a patient with follicular conjunctivitis.

\section{PREPARATION OF ANTIGENS}

Antigens were prepared from infected yolk sacs of live chick embryos as described by Treharne $e t$ al. (1971), except that in addition to centrifugation at $800 \mathrm{~g}$ for 10 minutes antigens were further clarified by a second centrifugation at $10000 \mathrm{~g}$ for one hour at $4^{\circ} \mathrm{C}$ and adjusted to $5 \%(\mathrm{~W} / \mathrm{V})$ of the original yolk sac suspension.

Pooled antigen suspensions were prepared by mixing together equal volumes of individual $5 \%$ antigen suspensions. These suspensions were stored at $-70^{\circ} \mathrm{C}$ and were allowed to undergo only three freeze-thaw cycles before being discarded.

\section{ANTIGEN SYSTEMS}

\section{System A Thirteen separate subgroup A chlamydial antigens}

The full range of individual serotypes as used in the full micro-IF test for detecting $C$. trachomatis typespecific antibody-that is, TRIC serotypes A, B, C, D, E, F, G, H, I, and K and LGV serotypes L1, L2, and L3.

System B Two antigen pools: one from C. trachomatis and one from $\mathrm{C}$. psittaci

Pool 1 All subgroup A Chlamydia (C. trachomatis) -that is, pooled TRIC and LGV serotypes A, B, C, D, E, F, G, H, I, K, L1, L2, and L3.

Pool 2 Selected Chlamydia subgroup B (C. psittaci)

Table 1 Geographical distribution and clinical origin of 257 serotyped TRIC and LGV isolates of C. trachomatis

\begin{tabular}{|c|c|c|c|c|c|c|c|c|c|c|c|c|c|c|}
\hline \multirow[t]{2}{*}{ Geographical area } & \multicolumn{14}{|c|}{ Serotype } \\
\hline & $A$ & $B$ & $B a$ & $C$ & $D / E$ & $F$ & $G$ & $\boldsymbol{H}$ & $I$ & $J$ & $\boldsymbol{K}$ & $L I$ & $L 2$ & $L 3$ \\
\hline \multicolumn{15}{|l|}{$\begin{array}{l}\text { N. Africa } \\
\text { Tunisia, Egypt, Sudan, Gambia, and }\end{array}$} \\
\hline $\begin{array}{l}\text { Saudi Arabia } \\
\text { Asia }\end{array}$ & 26 & 6 & 1 & 1 & 1 & 1 & 一 & 一 & - & - & 一 & 一 & 一 & - \\
\hline $\begin{array}{l}\text { Iran and Afghanistan } \\
\text { S.W. Pacific }\end{array}$ & 2 & 40 & - & 34 & 9 & 1 & 1 & 2 & - & - & - & 一 & - & - \\
\hline $\begin{array}{l}\text { Australia } \\
\text { America }\end{array}$ & - & 2 & - & 1 & - & 一 & - & 一 & - & 一 & - & 一 & - & - \\
\hline $\begin{array}{l}\text { USA and Guatemala } \\
\text { Europe }\end{array}$ & - & 一 & - & 1 & 5 & 2 & 1 & 1 & 1 & 2 & 1 & 2 & 12 & - \\
\hline UK and Denmark & - & 2 & - & 1 & 63 & 9 & 12 & 5 & 2 & 1 & 3 & 1 & 一 & 2 \\
\hline \multicolumn{15}{|l|}{$\begin{array}{l}\text { Clinical site and type of disease } \\
\text { Ocular isolates }\end{array}$} \\
\hline Hyperendemic trachoma & 28 & 48 & 1 & 36 & 2 & - & - & - & - & - & - & - & - & - \\
\hline $\begin{array}{l}\text { Paratrachoma } \\
\text { Genital or lymph node isolates }\end{array}$ & - & 2 & - & - & 32 & 4 & 6 & 1 & - & - & - & - & - & 一 \\
\hline Paratrachoma & - & - & - & 2 & 44 & 9 & 8 & 7 & 3 & 3 & 4 & - & - & - \\
\hline $\begin{array}{l}\text { LGV } \\
\text { Total }\end{array}$ & $\overline{-}$ & - & - & - & - & - & $\rightarrow$ & - & - & - & - & 3 & 12 & 2 \\
\hline Total & 28 & 50 & 1 & 38 & 78 & 13 & 14 & 8 & 3 & 3 & 4 & 3 & 12 & 2 \\
\hline
\end{tabular}


serotypes pooled-that is, 33-L, IOL-395, A-22/18, and A-10.

System C Four antigen pools-three from C. trachomatis and one from C. psittaci

Pool 1 All hyperendemic TRIC agent serotypes pooled-that is, A, B, and C.

Pool 2 All paratrachoma TRIC agent serotypes pooled-that is, D, E, F, G, H, I, and $\mathrm{K}$ (this pool does not include UW-36/GCx proposed as TRIC serotype J (S. P. Wang, personal communication)). Pool 3 All $C$. trachomatis lymphogranuloma venereum serotypes pooled - that is, $\mathrm{L} 1, \mathrm{~L} 2$, and $\mathrm{L} 3$. Pool 4 Selected Chlamydia subgroup B (C.psittaci) serotypes pooled as in system B, pool 2-that is, 33-L, IOL-395, A-22/18, and A-10.

System D Four antigen pools-three from C. trachomatis and one from $\mathrm{C}$. psittaci

Pool 1 Selected hyperendemic TRIC agent serotypes pooled-that is, B and C.

Pool 2 Selected paratrachoma TRIC agent serotypes pooled, E, G, H, and I.

Pool 3 Selected C. trachomatis LGV serotypes pooled-that is, L2 and L3.

Pool 4 Selected subgroup B (C. psittaci) serotypes pooled as in system B, pool 2-that is, $33-\mathrm{L}$, IOL-395, A-22/18, and A-10.

System E Seven selected C. trachomatis serotypes These comprised (1) type B, hyperendemic trachoma; (2) type $\mathrm{C}$, hyperendemic trachoma; (3) type $\mathrm{E}$, paratrachoma; (4) type $\mathrm{G}$, paratrachoma; (5) type $\mathrm{H}$, paratrachoma; (6) type I, paratrachoma; and (7) type L3, LGV.

SER A

All sera were absorbed before use with an equal volume of $40 \%$ uninfected normal yolk sac for 60 minutes at $37^{\circ} \mathrm{C}$ and overnight at $+4^{\circ} \mathrm{C}$. The sera used to select the most suitable antigen system were from (a) mice hyperimmunised with specific serotype antigens, and $(b)$ patients with chlamydial infection yielding serotyped isolates.

Additional sera from patients with a wide variety of chlamydial infections, or suspected chlamydial infections, were subsequently titrated against all individual serotypes and the antigen system $\mathrm{C}$ selected on the basis of testing with the above sera (a) and $(b)$.

DETECTION OF SPECIFIC ANTIBODY Sera were titrated and the immunofluorescent staining technique was carried out as described previously (Dwyer et al., 1972).

\section{Results}

The results of serotyping 257 isolates of subgroup A Chlamydia are shown in Table 1 . Nearly all isolates from hyperendemic trachoma in Asia or Africa serotype as TRIC serotypes A, B, or C. On the other hand, isolates from ocular or genital infections of paratrachoma (Jones, 1975) in the UK or USA generally serotype as TRIC types D, E, F, G, H, I, $\mathbf{J}$, or $\mathrm{K}$. All isolates from cases clinically diagnosed as LGV have typed as one or other of the three LGV serotypes $\mathrm{L} 1, \mathrm{~L} 2$, or $\mathrm{L} 3$.

Table 2 compares the sensitivity of the various systems and indicates that system $\mathrm{C}$ gives the least reduction in sensitivity as compared with system $\mathrm{A}$.

Table 3 shows the average percentage reactions against individual serotypes and against the three C. trachomatis (subgroup A) serotype pools of 을 system $C$, which includes also a fourth pool containing strains representative of $C$. psittaci (subgroup B) agents. Sera from patients whose isolates typed as $\mathrm{A}, \mathrm{B}$, or $\mathrm{C}$ (hyperendemic trachoma serotypes) showed the strongest reactions to pool 1. Sera from patients whose isolates typed as D, E, F. G, H, I, or $\mathrm{K}$ (paratrachoma serotypes) showed strongest reactions to pool 2, although some strong crossreactions to pool 3 (LGV group) were seen. Monospecific sera from mice hyperimmunised with L2 strains and five sera of patients from whom an L2 serotype was isolated reacted most strongly with pool 3. Finally, sera from mice hyperimmunised with subgroup B chlamydia and sera from patients with a clinical diagnosis of psittacosis cross-reacted solely with pool 4 (C. psittaci) antigens.

Table 4 summarises the results of titrations of human sera against the four antigen pools of system $\mathrm{C}$ and shows the range of cross-reactions. To determine individual titres to the infecting serotype of type-specific antibody present in any serum further titrations would be required against only the limited selections of single serotype antigens listed in the right hand column of Table 4 .

Sera from patients suffering from a wide variety $N$ of diseases, some of which were proved chlamydial $N$ infections, were tested against the whole range of N

Table 2 Relative sensitivity of the micro-IF test using various antigen systems indicating reduction in geometric mean titre as compared with titre to single homologous antigens of system $A$

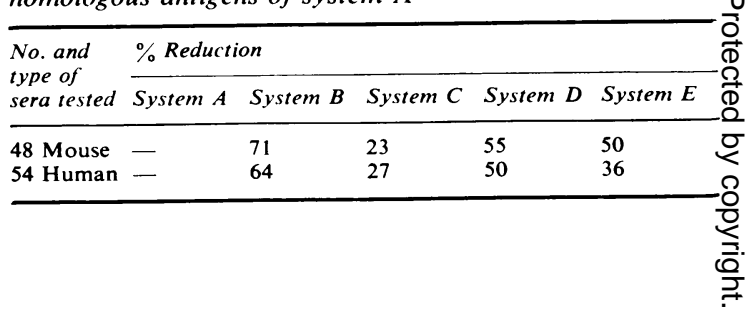


Table 3 Micro-IF antibody expressed as percentages of the homologous reactions in sera from patients from whom a chlamydial isolate was serotyped and in 48 sera from mice hyperimmunised with known chlamydial serotypes

\begin{tabular}{|c|c|c|c|c|c|c|c|c|c|c|c|c|c|c|c|c|c|c|c|c|}
\hline \multirow[t]{2}{*}{ Sera } & \multirow{2}{*}{$\begin{array}{l}\text { Micro-IF } \\
\text { serotype } \\
\text { of isolate }\end{array}$} & \multirow{2}{*}{$\begin{array}{l}\text { No. of } \\
\text { sera }\end{array}$} & \multicolumn{4}{|c|}{ Pooled antigens: system $C$} & \multicolumn{13}{|c|}{ Single antigens } & \multirow{2}{*}{$\begin{array}{l}\text { Reciprocal } \\
\text { geom. mean } \\
\text { homologous } \\
\text { titre }\end{array}$} \\
\hline & & & $\begin{array}{l}\text { Pool 1 } \\
(A, B, C)\end{array}$ & $\begin{array}{l}\text { Pool } 2 \\
(D, E, F, \\
G, H, I, \\
K)\end{array}$ & $\begin{array}{l}\text { Pool } 3 \\
(L 1, L 2, \\
L 3)\end{array}$ & $\begin{array}{l}\text { Pool } 4 \\
\text { (EAE, } \\
\text { IOL-395, } \\
\text { A-IO, } \\
33-L)\end{array}$ & $A$ & $\boldsymbol{B}$ & $\dot{C}$ & $D$ & $E$ & $F$ & $G$ & $\boldsymbol{H}$ & $I$ & $\boldsymbol{K}$ & $L I$ & $L 2$ & L3 & \\
\hline Human & $\mathbf{A}$ & 5 & 100 & - & - & - & 100 & - & 10 & - & - & - & - & - & - & - & - & - & - & 97 \\
\hline Mouse & A & 4 & 100 & - & - & - & 100 & - & 25 & - & - & - & - & - & - & - & - & - & - & 128 \\
\hline Human & B & 5 & 100 & 16 & 29 & - & - & 100 & - & - & 16 & - & - & - & - & - & - & 28 & - & 64 \\
\hline Mouse & B & 4 & 100 & 13 & 13 & - & - & 100 & - & - & - & - & - & - & - & - & - & - & - & 512 \\
\hline Human & C & 5 & 100 & - & - & - & 19 & - & 100 & - & - & - & - & - & - & 14 & - & - & - & 125 \\
\hline Mouse & C & 4 & 100 & - & - & - & 25 & - & 100 & - & - & - & - & - & - & - & - & - & - & 512 \\
\hline Human & D & 5 & - & 100 & 29 & - & - & - & - & 100 & 100 & - & - & - & - & - & - & 25 & 33 & 147 \\
\hline Mouse & D & 4 & - & 100 & 25 & - & - & - & - & 100 & 25 & - & 13 & - & - & - & 13 & 26 & 25 & 256 \\
\hline Human & $\mathbf{E}$ & 5 & 19 & 100 & 44 & - & - & 11 & - & 100 & 100 & - & - & - & - & 16 & 25 & 44 & 14 & 147 \\
\hline Mouse & $\overline{\mathbf{E}}$ & 4 & - & 100 & 44 & - & - & - & - & 100 & 100 & - & - & - & - & - & 13 & 25 & 13 & 123 \\
\hline Human & $\mathbf{F}$ & 5 & - & 100 & 25 & - & - & - & - & - & - & 100 & 22 & - & - & - & - & - & 11 & 42 \\
\hline Mouse & $\mathbf{F}$ & 4 & - & 100 & 13 & - & - & - & - & - & - & 100 & 13 & - & - & - & - & - & - & 128 \\
\hline Human & $\mathbf{G}$ & 5 & - & 100 & 66 & - & - & - & - & - & - & 22 & 100 & - & - & 44 & - & 14 & 44 & 256 \\
\hline Mouse & G & 4 & - & 100 & 13 & - & - & - & - & - & - & 50 & 100 & - & - & 10 & - & - & 13 & 256 \\
\hline Human & $\mathbf{H}$ & 3 & - & 100 & - & - & - & - & - & - & - & - & - & 100 & - & - & - & - & - & 256 \\
\hline Mouse & $\mathbf{H}$ & 4 & - & 100 & - & - & - & - & - & - & - & - & - & 100 & - & - & - & - & - & 64 \\
\hline Human & I & 2 & 13 & 100 & - & - & - & - & - & - & - & - & - & - & 100 & - & - & - & - & 90 \\
\hline Mouse & I & 4 & - & 100 & - & - & - & - & - & - & - & - & - & - & 100 & - & - & - & - & 256 \\
\hline Human & $\mathbf{K}$ & 4 & - & 100 & 50 & - & - & - & - & - & - & 10 & 13 & - & - & 100 & - & - & 50 & 215 \\
\hline Mouse & $\mathbf{K}$ & 4 & - & 100 & 50 & - & - & - & - & - & - & - & - & - & - & 100 & - & - & 50 & 1024 \\
\hline Human & L2* & 5 & - & 44 & 100 & - & - & 16 & - & 25 & 44 & - & - & - & - & 33 & 38 & 100 & 38 & 512 \\
\hline Mouse & $\mathbf{L} 2$ & 4 & 13 & 50 & 100 & - & - & - & - & 50 & 25 & - & - & - & - & 50 & 25 & 100 & 25 & 128 \\
\hline Human & Psittacosis & & - & - & - & 100 & - & - & - & - & - & - & - & - & - & - & - & - & - & 588 \\
\hline Mouse & Psittacosis & 4 & - & 一 & - & 100 & - & - & - & - & - & - & - & - & - & - & - & - & - & 64 \\
\hline
\end{tabular}

* Four sera kindly supplied by Dr. R. N. Philip, Montana, USA

tSera from five cases of human psittacosis (no isolation made)

Note. No sera available for $L 1$ or $L 3$ serotypes

Tabie 4 Percentage cross-reactions, with antigen pools, of 98 sera from patients with typed chlamydial isolates

\begin{tabular}{|c|c|c|c|c|c|c|}
\hline \multirow{2}{*}{$\begin{array}{l}\text { Type o: } \\
\text { isolate }\end{array}$} & \multirow{2}{*}{$\begin{array}{l}\text { No. of } \\
\text { sera }\end{array}$} & \multicolumn{3}{|c|}{ Subgroup A Chlamydia (C. trachomatis) } & \multirow{2}{*}{\multicolumn{2}{|c|}{$\begin{array}{l}\text { Subgroup B Chlamydia Further titrations against } \\
\text { single antigens necessary } \\
\begin{array}{ll}\text { Pool } 4 & \text { to define the infecting } \\
\text { C. psittaci type } & \text { serotypes } \\
\text { isolates } & \end{array}\end{array}$}} \\
\hline & & $\begin{array}{l}\text { Pool } 1 \\
\text { (Hyperendemic } \\
\text { trachoma serotypes) }\end{array}$ & $\begin{array}{l}\text { Pool } 2 \\
\text { (Paratrachoma } \\
\text { serotypes) }\end{array}$ & $\begin{array}{l}\text { Pool } 3 \\
\text { (Lymphogranuloma } \\
\text { venereum serotypes) }\end{array}$ & & \\
\hline $\begin{array}{l}\text { A } \\
\text { B } \\
\text { C } \\
\text { D } \\
\text { E } \\
\text { F } \\
\text { G } \\
\text { H } \\
\text { I } \\
\text { K } \\
\text { L1 } \\
\text { L2 } \\
\text { L3 } \\
\text { Subgroup }\end{array}$ & $\begin{array}{r}11 \\
8 \\
10 \\
10 \\
12 \\
6 \\
8 \\
5 \\
5 \\
3 \\
4 \\
2 \\
7 \\
2 \\
10\end{array}$ & $\begin{array}{l}100 \\
100 \\
100 \\
0-6 \\
0-13\end{array}$ & $\begin{array}{l}6-13 \\
\begin{array}{|l|}100 \\
100 \\
100 \\
100 \\
100 \\
100 \\
100 \\
0-13 \\
25-50 \\
0-25\end{array}\end{array}$ & $\begin{array}{l}6-13 \\
6-25 \\
13-50 \\
6-25 \\
13-50 \\
50-100 \\
100 \\
100 \\
100\end{array}$ & 100 & $\begin{array}{l}(\mathrm{A}, \mathrm{C}) \\
(\mathrm{A}, \mathrm{C}) \\
(\mathrm{D}, \mathrm{E}, \mathrm{F}, \mathrm{G}) \\
(\mathrm{D}, \mathrm{E}, \mathrm{F}, \mathrm{G}) \\
(\mathrm{D}, \mathrm{E}, \mathrm{F}, \mathrm{G}) \\
(\mathrm{D}, \mathrm{E}, \mathrm{F}, \mathrm{G}) \\
(\mathrm{H}, \mathrm{I}) \\
(\mathrm{H}, \mathrm{I}) \\
\overline{(L 1}, \mathrm{L3}) \\
\overline{-} \\
\text { (L1, L2) } \\
\text { Not known }\end{array}$ \\
\hline
\end{tabular}

individual micro-IF antigens and against the pooled antigens of system $\mathrm{C}$. The type-specificity of antichlamydial antibody in sera of 35 Chlamydia isolationpositive men with urethritis is shown in the right hand column of Table 5 and indicates those sera which show at least a fourfold higher cross-reaction to the serotype indicated than to any of the other individual micro-IF types. Two or more serotype antigens have been listed under the micro-IF type reaction pattern when the cross-reactivity of that serum has been equal or showed only a twofold difference in titre to two or more serotype antigens. Eighteen out of 35 men $(51 \%)$ had chlamydial antibody titres of $1: 8$ or greater. Sixteen out of these 
Table 5 Micro-IF reciprocal titres to the whole range of chlamydial antigens (system A) and to the pooled antigens of system $C$ with sera from 35 isolation-positive men with non-specific urethritis

\begin{tabular}{|c|c|c|c|c|c|c|c|c|c|c|c|c|c|c|c|c|c|c|c|c|}
\hline \multirow[t]{2}{*}{ Serum No. } & \multicolumn{4}{|c|}{ Pooled antigens: system $C$} & \multicolumn{14}{|c|}{ Pooled antigens: system $A$} & \multirow[t]{2}{*}{ Titre } & \multirow{2}{*}{$\begin{array}{l}\text { Micro-IF } \\
\text { type reaction } \\
\text { pattern }\end{array}$} \\
\hline & $\begin{array}{l}\text { Pool } 1 \\
(A, B, \\
C)\end{array}$ & $\begin{array}{l}\text { Pool } 2 \\
(D, E, \\
F, G, \\
H, \\
I, K)\end{array}$ & $\begin{array}{l}\text { Pool } 3 \\
(L 1, L 2, \\
L 3)\end{array}$ & $\begin{array}{l}\text { Pool } 4 \\
\text { (EAE, } \\
\text { IOL- } \\
395, \\
A-10, \\
33-L)\end{array}$ & $A$ & B & $C$ & $D$ & $E$ & $F$ & $\boldsymbol{G}$ & $H$ & $I$ & $K$ & $L 1$ & $L 2$ & $L 3$ & Subgroup B & & \\
\hline 2211 & 一 & 16 & 16 & - & - & - & - & - & 一 & 8 & 8 & - & - & 32 & - & - & 8 & 一 & 32 & $\mathbf{K}$ \\
\hline 2226 & - & 32 & 16 & - & $\longrightarrow$ & 一 & - & 16 & 16 & - & - & - & 一 & 32 & - & 8 & 16 & - & 32 & $\mathbf{K}$ \\
\hline 2237 & - & 一 & - & 16 & - & - & - & 一 & - & 一 & 一 & 一 & 一 & - & - & - & - & 16 & 16 & Subgroup B \\
\hline 2375 & - & 8 & 8 & 一 & 一 & - & - & 8 & 8 & 一 & - & - & 一 & - & 一 & 8 & - & - & 8 & D-E-L2 \\
\hline 2466 & - & 8 & 8 & - & 一 & - & - & - & - & 一 & - & - & 一 & 8 & - & 8 & 一 & - & 8 & K-L 3 \\
\hline 2468 & 8 & 64 & 64 & 16 & 一 & - & - & 64 & 128 & 32 & 32 & - & - & 32 & 32 & 64 & 32 & 一 & 128 & D-E-L2 \\
\hline 2568 & - & 64 & 16 & - & 一 & 8 & - & 16 & 64 & - & - & - & - & 16 & 32 & 32 & 16 & - & 64 & $\mathrm{E}$ \\
\hline 2793 & 一 & 16 & 16 & - & 一 & - & - & - & - & - & - & 一 & - & 32 & 一 & 一 & 8 & - & 32 & $\mathbf{K}$ \\
\hline 3427 & - & 8 & 16 & - & 一 & 一 & - & 8 & 8 & 8 & - & - & - & 16 & 8 & 8 & 16 & - & 16 & K-L 3 \\
\hline 3592 & 一 & 16 & 16 & - & - & - & - & $\longrightarrow$ & - & - & 8 & 一 & 一 & 32 & - & - & 16 & - & 32 & K-L3 \\
\hline 4130 & - & - & 8 & 32 & 一 & - & - & 一 & - & 8 & 8 & 一 & - & 8 & 8 & 8 & 8 & 32 & 32 & Subgroup B \\
\hline 4412 & - & 64 & 16 & 一 & - & - & - & - & - & 128 & 32 & 一 & - & 16 & 一 & - & 16 & - & 128 & $\mathrm{~F}$ \\
\hline 4292 & - & 128 & 64 & 16 & - & 一 & - & - & - & - & - & $\longrightarrow$ & - & 128 & - & 16 & 32 & 8 & 128 & $\mathbf{K}$ \\
\hline 4411 & - & 32 & 16 & - & - & - & 一 & 8 & 8 & 64 & 16 & 一 & 一 & 16 & - & 8 & 16 & - & 64 & $F$ \\
\hline 6828 & 一 & 16 & - & - & - & - & - & - & - & - & - & - & - & 64 & - & 一 & 一 & - & 64 & K \\
\hline 13186 & - & 256 & 128 & 16 & - & - & - & 16 & 16 & 64 & 128 & - & - & 512 & 16 & 16 & 256 & - & 512 & K-L3 \\
\hline 4166 & - & 16 & - & - & - & - & - & 16 & 8 & - & - & - & - & - & - & - & - & - & 16 & D-E \\
\hline 4200 & - & 64 & 32 & - & 一 & - & - & 64 & 64 & - & - & - & - & 16 & 8 & 32 & 16 & - & 64 & D-E \\
\hline sera) & - & - & - & - & - & - & - & - & - & - & - & - & - & - & - & - & - & - & - & - \\
\hline
\end{tabular}

Table 6 Reciprocal geometric mean titres to pooled chlamydial antigens of system $C$ and predominant type-specific antibody to single antigens of system $A$ in 531 patients with proved or suspected chlamydial infection

\begin{tabular}{|c|c|c|c|c|c|c|}
\hline Clinical description & $\begin{array}{l}\text { Geographical } \\
\text { area }\end{array}$ & $\begin{array}{l}\text { No. of } \\
\text { sera }(S) \\
\text { or } \\
\text { tears }(T)\end{array}$ & $\begin{array}{l}\text { Geometric } \\
\text { mean titre }\end{array}$ & $\begin{array}{l}\% \text { with } \\
\text { antibody } \\
\text { titre of } 1: 8 \\
\text { or greater }\end{array}$ & $\begin{array}{l}\text { Predominantly cross- } \\
\text { reactive antigen pools }\end{array}$ & $\begin{array}{l}\text { Predominant type } \\
\text { specific antibody to } \\
\text { single antigens } \ddagger\end{array}$ \\
\hline \multicolumn{7}{|l|}{ Trachoma } \\
\hline Isolation + ve hyperendemic trachoma & Tunisia & $21(\mathrm{~S})$ & $1: 57^{\dagger}$ & 90 & Hyperendemic trachoma & $A, B,(C)$ \\
\hline Isolation + ve hyperendemic trachoma & , & $20(\mathrm{~T})$ & $1: 28+$ & 75 & " & $\mathrm{A}, \mathrm{B},(\mathrm{C})$ \\
\hline Isolation - ve hyperendemic trachoma & ", & 73 (S) & $1: 9$ & 70 & ," & A, B, (C) \\
\hline Isolation - ve hyperendemic trachoma & & $71(\mathrm{~T})$ & $1: 2$ & 20 & 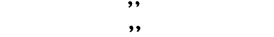 & $\mathrm{A}, \mathrm{B},(\mathrm{C})$ \\
\hline \multicolumn{7}{|l|}{$\begin{array}{l}\text { Mothers and fathers of TRIC agent } \\
\text { ve babies with ON }\end{array}$} \\
\hline Mothers isolation + ve & UK & $14(S)$ & $1: 122$ & 100 & Patatrachoma & $D, E, F, G, K, C / J$ \\
\hline Mothers $\{$ isolation - ve & , & $2(\mathrm{~S})$ & $1: 64$ & 100 & , & K, B \\
\hline Fathers $\}$ isolation $+v e$ & ", & $4(S)$ & $1: 23$ & 76 & ”, & $\mathrm{D}, \mathrm{E}, \mathrm{G}, \mathrm{K}$ \\
\hline Fathers \{isolation - ve & 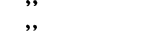 & 12 (S) & $1: 4$ & 50 & ," & $\mathrm{D}, \mathrm{E}, \mathrm{F}, \mathrm{K}, \mathrm{B}$ \\
\hline \multicolumn{7}{|l|}{ Ocular paratrachoma of adults } \\
\hline Isolation + ve & , & $15(S)$ & $1: 93$ & 100 &, & D, E, F, G, H, I \\
\hline \multicolumn{7}{|l|}{ Non-specific urethritis in men } \\
\hline Isolation + ve & & $35(\mathrm{~S})$ & $1: 37 \dagger$ & 51 &, & $\mathrm{D}, \mathrm{E}, \mathrm{F}, \mathrm{K}$ \\
\hline Isolation - ve & ", & 30 (S) & $1: 2$ & 10 & ”, & $(\mathrm{D}, \mathrm{E}, \mathrm{K})$ \\
\hline \multicolumn{7}{|l|}{ Cervicitis in women } \\
\hline Isolation + ve & , & $117(\mathrm{~S})$ & $1: 66 \dagger$ & 77 & , & $\mathrm{D}, \mathrm{E}, \mathrm{F}, \mathrm{G}, \mathrm{H}, \mathrm{K}(\mathrm{C} / \mathrm{J})$ \\
\hline Isolation - ve & $"$ & 79 (S) & $1: 2$ & 14 & $"$ & $\mathrm{D}, \mathrm{E}, \mathrm{F}, \mathrm{G}, \mathrm{K}$ \\
\hline \multicolumn{7}{|l|}{ Lymphogranuloma venereum } \\
\hline Isolation + ve & $\begin{array}{l}\text { USA and } \\
\text { UK }\end{array}$ & $8(S)$ & $1: 512$ & 100 & , & L2, L3 \\
\hline Psittacosis* & UK & $30(S)$ & $1: 240$ & 100 & Subgroup B & Subgroup B \\
\hline
\end{tabular}

* Isolation not attempted

+ GMT of positive sera or tears

$\ddagger$ Parentheses indicate less than $5 \%$ with type-specific antibody to these serotypes

18 men showed the highest levels of antibody to pool 2 (paratrachoma serotypes). The other two men showed strongest reactions to subgroup $B$ antigens of pool 4.
As a control series, sera from 20 patients with isolation-positive ocular infection due to adenovirus and 20 patients with isolation-positive herpes virus ocular infection were tested. The geometric 
mean titre of antibody to each of the 4 chlamydial antigen pools was less than $1: 8$, nor was chlamydial antibody detected in any of the individual sera at the initial dilution of $1: 8$.

Table 6 summarises the results using system $C$ with 531 sera from persons with proved or suspected chlamydial infection. In hyperendemic trachoma the titres of sera and tears were significantly higher in isolation-positive cases than in those from whom Chlamydia was not isolated. In all cases sera reacted most strongly with the hyperendemic trachoma antigen pool. This was subsequently confirmed by titration against single antigens.

Relatively high antibody levels (1:114), predominantly to paratrachoma antigens, were detected in all mothers of babies with ophthalmia neonatorum due to TRIC agent. Fewer fathers had detectable levels of antibody (63\%) and, although the typespecificity of antibody paralleled that of the mothers, the geometric mean titre was much lower than the $1: 8$ level.

Sera from patients presenting in the UK with ocular infection due to Chlamydia showed high geometric mean titres $(1: 93)$ to the paratrachoma antigen pool.

In only $51 \%(19 / 53)$ of men with Chlamydia isolation-positive, non-specific urethritis (NSU) could antibody to Chlamydia be detected. The geometric mean titre in these 35 men was $1: 8$, but it was $1: 37$ in those 19 men who developed antibody. Only $10 \%(3 / 30)$ men with Chlamydia isolation-negative NSU developed antibody, the geometric mean titre of all 30 men being less than $1: 2$, but it was $1: 64$ in those who developed antibody. All sera that were positive in each of these groups of men reacted most strongly with the pooled paratrachoma antigens.

Eight sera from isolation-positive cases of lymphogranuloma venereum from the UK and USA developed high geometric mean antibody levels $(1: 512)$ to chlamydial antigens in the LGV pool. These sera, however, showed strong cross-reactions with the patatrachoma antigen pool.

Finally, all 30 sera from patients with clinically diagnosed psittacosis developed high levels of antibody (geometric mean titre $1: 240$ ) to the selected antigens in the subgroup B pool, with no cross-reactions at a 1:8 level with the other antigen pools.

\section{Discussion}

Wang and Grayston (1971) using sera from infected monkeys and Dwyer et al. (1972) using sera from human chlamydial infections showed the presence of type-specific antibody to $C$. trachomatis infections using representative antigens from the micro-IF test described by Wang and Grayston (1970). Hanna et al. (1972), Wang and Grayston (1974), Philip et al. (1974), and Treharne et al. (in preparation) have subsequently utilised this indirect immunofluorescence test to detect type-specific chlamydial antibodies in a wide range of $C$. trachomatis infections. Jones and Treharne (1974) reported that this test was not only able to detect type-specific antibody to subgroup A chlamydial infections but by using appropriate antigens could clearly distinguish subgroup A chlamydial infections from subgroup B (C. psittaci) infections.

Thus the detection of type-specific antibodies to Chlamydia using the micro-IF test as described by Wang and others (1973) and Treharne and others (1973) is practicable. To date, however, some 12 TRIC serotypes and 3 LGV serotypes have been described, so the work required to titrate or even screen sera against such a large range of antigens severely limits the usefulness of the test in large scale serodiagnosis.

The five levels of precision required, for different purposes, of a serodiagnostic test for chlamydial infection are as follows: (1) To diagnose chlamydial infection of any sort regardless of whether it is caused by subgroup A (C. trachomatis) or subgroup B (C. psittaci) organisms, thus serving the same function as the present insensitive CF test. (2) To diagnose chlamydial infection by subgroup B Chlamydia ( $C$. psittaci) agents whatever their nature and origin. (3) To diagnose chlamydial infection by subgroup A Chlamydia (C. trachomatis) agents, whether the agent is one that is usually associated with hyperendemic trachoma or sexually transmitted ocular or genital disease (paratrachoma) or lymphogranuloma venereum. (4) To diagnose chlamydial infection by subgroup A Chlamydia. ( $C$ trachomatis) and to indicate whether this infection was due to a hyperendemic TRIC agent serotype, a paratrachoma TRIC serotype, or an LGV serotype, there being important epidemiological and prognostic differences across the spectrum of agents. (5) To diagnose chlamydial infection and to indicate the precise serotype responsible (or the small cluster of serotypes in the case of more broadly reacting sera).

The present study indicates clearly that system C best provides a practicable routine test that meets, in a single step, the first four of these diagnostic requirements and simplifies the work required for (5). For narrower survey purposes the test can be simplified by omitting one or more of the four antigen pools, but it should be remembered that this incurs the possibility of falsely interpreting crossreactions with another pool, especially between the three types of subgroup A Chlamydia at present all 
referred to as Chlamydia trachomatis-namely, pool 1, pool 2, and pool 3. For those purposes requiring the most precise information concerning the particular serotype responsible one further simple titration is required using only a small number of antigens (Table 4).

The use of two pools in system B representative of each of the two chlamydial subgroups instead of the three pools for subgroup A and one for subgroup B, as in system $C$, resulted in marked reduction of the sensitivity of the test. So also did pooling of selected isolates representative of the more highly crossreactive serotypes, as in system $D$.

The use of single selected, more highly crossreactive serotype antigens (system $E$ ) offered certain advantages over any system using pooled antigens, but while it proved to be almost as sensitive as system $C$ it still required that the sera should be titrated against a minimum of seven subgroup A antigens as opposed to only three pooled antigens used in system C. Furthermore, its use did not materially simplify the subsequent titrations needed to determine the complete type-specificity of the antibody response.

Thus system C offers considerable savings in time, materials, and costs. By using screening titrations of the sera-for example $1: 8,1: 32$, and $1: 128$ dilutions -50-100 sera could be examined in one day, only positive sera being fully titrated (if necessary) either against the pooled antigens or, if required, against selected single antigens representative of individual serotypes.

To evaluate the modified test, sera from a range of chlamydial infections from different geographical locations were examined using system $C$ (four antigen pools representative of the three epidemiological $C$. trachomatis groups and one $C$. psittaci group). The type-specific antibody in all positive sera was subsequently determined by titration against single antigens as required. On no occasion in any of 531 tears or sera tested was the type-specificity of antibody wrongly indicated by the pooled antigen. Thus a specimen showing the highest cross-seaction to pool 1 (hyperendemic trachoma group) always proved to have the highest level of type-specific antibody to either TRIC type A, B, or C, and a specimen showing the highest cross-reaction to pool 2 (paratrachoma group) was subsequently always found to have the highest level to TRIC type D, E, $\mathrm{F}, \mathrm{G}, \mathrm{H}, \mathrm{I}$, or $\mathrm{K}$.

It is of interest that the lowest levels of typespecific serum antibody in chlamydial isolationposititive patients were found in men presenting with non-specific urethritis ( 1 in 37) and isolation-positive fathers of babies with TRIC agent ophthalmia neonatorum ( 1 in 23). Isolation-positive patients with hyperendemic trachoma in Tunisia had a slightly higher geometric mean titre of 1 in 57 (the geometric mean titre of antibody in tear fluids of the same patients was 1 in 28). The highest levels of antibody to TRIC agent infection were found in chlamydial isolation-positive women presenting with cervicitis (1 in 66), isolation-positive mothers of babies with ophthalmia neonatorum due to TRIC agent ( 1 in 122), and in adult patients in the UK presenting with ocular paratrachoma infection due to TRIC agent ( 1 in 93), in nearly all of whom there was also genital infection.

The titre of chlamydial antibody thus appears to correlate with the nature of the infection: highest levels of antibody are produced by the more invasive LGV and $C$. psittaci organisms. Generally, women with genital infection appear to have higher levels than men. The reason for this may be that in addition to having a larger area of infection the women often remain asymptomatic for long periods of time, thus providing a larger and longer antigenic stimulation than usually occurs in men. The fact that patients with ocular infections in the UK had higher titres than patients in a hyperendemic area such as Tunisia is not surprising as most of the former patients had genital infections due to Chlamydia concurrent with their ocular infections. Any analysis of this sort, however, should be interpreted with caution as the sera were collected from a wide age range of patients and at various times during the course of their infections.

In most cases antibody could be detected in chlamydial isolation-positive patients. The main exceptions were in urethral isolation-positive males with non-specific urethritis due to TRIC agent and in urethral isolation-positive males who were the fathers of babies with ophthalmia neonatorum due to TRIC agent. This may suggest that in these men the infection was mild, or of short duration, thus providing little antigenic stimulus.

In common with Dwyer et al. (1972) and Wang and Grayston (1974), we have noted more broadly cross-reactive sera in LGV isolation-positive patients. Some broadly cross-reactive sera have come from patients with infections due to paratrachoma serotypes, but not in sufficient number to require cross absorption studies as carried out by Philip et al. $\underset{\gtrless}{2}$ (1974) and Briones et al. (1975). We have accepted o a fourfold or higher titre of antibody to any indi- $\overparen{\Phi}$ vidual serotype antigen as positive indication of infection by that serotype. This has been consistently borne out by numerous replicate titrations on single serum specimens from Chlamydia-positive patients whose isolates have been serotyped.

We thank Dr E. M. C. Dunlop and his colleagues for 
sera from patients with genital infection, Dr R. N. Phillip (USA) for sera from patients with lymphogranuloma venereum infection, and Professor N. R. Grist for sera from patients with psittacosis infection. The sera and tears from children with hyperendemic trachoma in southern Tunisia were collected in a collaborative study with Drs $T$. Daghfous, M. Messadi of the Institut d'Ophthalmologie de Tunis, and Dr Dawson of the Procter Institute, University of California. The sera from persons with hyperendemic trachoma in southern Iran were collected in a collaborative study with Professor H. Mohsenine and Dr J. Allami of the School of Public Health, University of Teheran, carried out with partial support from the Wellcome Trust, the Dulverton Trust, and the Hospital of St. John of Jerusalem. Finally, we are grateful to $\mathrm{Mr} \mathrm{R}$. J. Dines and Mr C. K. Yeo for their excellent technical assistance. The laboratory work was largely supported by a grant from the Department of Health and Social Security, and partially supported by the Wellcome Trust and the World Health Organisation.

\section{References}

Briones, O. C., Hanna, L., Jawetz, E., Dawson, C. R., and Ostler, H. B. (1975). Type-specific antibodies in human Chlamydia trachomatis infections of the eye. J. Immunol., 113, 1262-1270.

Dwyer, R. St. C., Treharne, J. D., Jones, B. R., and Herring, J. (1972). Results of micro-immunofluorescence tests for the detection of type-specific antibody in certain chlamydial infections. Brit. J. vener. Dis., 48, 452-459.

Hanna, L., Jawetz, E., Nabli, B., Hoshiwara, I., Ostler, B., and Dawson, C. (1972). Titrating and typing of serum antibodies in TRIC infections by immunofluorescence. J. Immunol., 108, 102-107
Jones, B. R. (1975). The prevention of blindness from trachoma. Trans. Ophthal. Soc. U.K., 95, 16-33.

Jones, B. R. and Treharne, J. D. (1974). Micro-immunofluorescence type-specific serological tests for Chlamydia infection. Proc. roy. Soc. Med., 67, 735-538.

Murray, E. S. (1964). Guinea pig inclusion conjunctivitis virus. I. Isolation and identification as a member of the psittacosis-lymphogranuloma-trachoma group. J. infect. Dis., 114, 1-12.

Philip, R. N., Casper, E. A., Gordon, F. B., and Quan, A. L. (1974). Fluorescent antibody responses to chlamydial infection in patients with lymphogranuloma venereum and urethritis. J. Immunol., 112, 2126-2134.

Schachter, J. and Meyer, K. F. (1969). Lymphogranuloma venereum. II. Characterization of some recently isolated strains. J. Bact., 99, 636-638.

Treharne, J. D., Darougar, S., and Jones, B. R. (1973). Characterization of a further micro-immunofluorescence serotype of Chlamydia: TRIC Type G. Brit. J. vener. Dis., 49, 295-300.

Treharne, J. D., Katzenelson, E., Davey, S. J., and Gray, S. J. (1971). Comparison of serotyping subgroup A chlamydial isolates by a one-way cross-reaction and by a two-way cross-reaction immunofluorescence test. In Trachoma and Related Disorders Caused by Chlamydial Agents, edited by R. L. Nichols, pp. 289-304. Excerpta Medica, Amsterdam.

Wang, S. P. and Grayston, J. T. (1970). Immunologic relationship between genital TRIC, lymphogranuloma venereum, and related organisms in a new micotiter indirect immunofluorescence test. Amer. J. Ophthal., 70, 367-374.

Wang, S. P. and Grayston, J. T. (1971). Local and systemic antibody response to trachoma eye infection in monkeys. In Trachoma and Related Disorders Caused by Chlamydial Agents, edited by R. L. Nichols, pp. 217-232. Excerpta Medica, Amsterdam.

Wang, S. P. and Grayston, J. T. (1974). Human serology in Chlamydia trachomatis infection with microimmunofluorescence. J. infect. Dis., 130, 388-397.

Wang, S. P., Grayston, J. T., and Gale, J. L. (1973). Three new immunologic types of trachoma-inclusion conjunctivitis organisms. J. Immunol., 110, 873-879. 